\title{
Оториноларингологична находка при пациенти с $\beta$-таласемия
}

\author{
П. Ненчева ${ }^{1}$, П. Руев ${ }^{1}$, М. Рангелова², \\ Д. Стоянова ${ }^{3}$, Д. Михайлов ${ }^{1}$ \\ ${ }^{1}$ Клиника УНГ-болести, МБАЛ - Стара Загора (Университетска) \\ ${ }^{2}$ Сектор по таласемии, НЦХТ - София \\ ${ }^{3}$ Кабинет по таласемия, СБАЛДБ - София
}

\section{Abstract}

ENT finding by patients with $\beta$ - thalassemia; Polina Nencheva, Petar Rouev, Mirela Rangelova, Denka Stoyanova, Dimitar Mihailov; E-mail: poli_nentcheva@hotmail.com

Introduction: The thalassemic syndromes are heterogeneous group of diseases. By this kind of haematological disorders the synthesis of $\beta$-polypeptid chains is decreased or missing. Except the thalassemic face and other symptoms of the $\beta$-thalassemia there are also some kinds of otorhinolaringological symptoms. Objective: The aim of this study is to determine the ENT status by patients with $\beta$-thalassemia under regular haemotransfusions and chelating therapy.

Study design: Multicentre prospective research - ENT Clinic, Paediatric Clinic, Therapeutic Clinic, Medicine Faculty, Stara Zagora; 6-th Therapeutic Department, District Hospital "Prof. S. Kirkovich", Stara Zagora; Sector of Thalassemia, Paediatric Hospital, Sofia; Sector of Thalassemia, National Centre of Transfusiology, Sofia.

Material and Methods: 63 patients with $\beta$-thalassemia under regular haemotransfusions and chelating therapy were examinated; ENT examination and audiometry.

Results: 1 patient with chronic serous otitis media and hearing loss; 3 patients with hypertrophy of the pharyngeal tonsils; 16 patients with hypertrophy of the tonsils; 5 patients with septum deviation; 60 patients of the patients with hypohromic nasal mucosa.

Key words: $\beta$-thalassemia, ENT status, ENT disorders

\section{Резюме}

Увод. Бета-таласемиите са разнородна група заболявания, при които липсва или е намален синтезът на $\beta$-полипептидните вериги на адултния хемоглобин. Освен таласемичен фациес и други характерни симптоми на $\beta$-таласемията в литературата са описани и редица оториноларингологични симптоми.

Цел. Целта на настоящото проучване е да се установи оториноларингологичният статус при пациенти с $\beta$-таласемия, про-

\section{Въведение}

\section{Клинична характеристика на $\beta$-таласемиите}

Бета-таласемиите са разнородна група заболявания, при които липсва или е намален синтезът на $\beta$-полипептидните вериги на адултния хемоглобин. Като последица от количествения дефицит в синтеза на една или повече структурно нормални глобинови вериги намалява общото количество на хемоглобина в еритроцитите, поради което таласемичните еритроцити са микроцитни и хипохромни. Това довежда до неефективна еритропоеза, хемолиза и различна по тежест анемия. В зависимост от генотипа се различават майор, интермедия, минор и тиха форма на таласемия [1].

Първите изяви на $\beta$-таласемията започват през първата година от живота при $60 \%$ от болните [2]. Ако състоянието не бъде навреме диагностицирано и съответно терапията не е адекватна, се проявява типичната клинична картина на $\beta$-таласемията и тези пациенти изостават във физическото си развитие. Кожата и видимите лигавици са бледи. Наблюдава се различен по интензитет иктер по склерите. Съществени са сплено- и хепатомегалията, скелетните промени, мускулната слабост. Обуславя се характерно лицево изражение с уголемяване на черепа, максиларна хипертрофия, която оголва горните зъби, зигоматичните кости изпъкват, основата на носа хлътва, очите са разположени монголоидно. Така описаното лице се нарича таласемичен фациес [3]. Обаче при пациентите, подложени на оптимален 
веждащи редовна хемотрансфузионна и хелатираща терапия. Дизайн на статията. Мултицентрово проспективно проучване от: Клиника ОРЛ, Клиника по педиатрия, Клиника по вътрешни болести - Медицински факултет - Стара Загора; VI Вьтрешно отделение - МБАЛ "Проф. Ст. Киркович" - Стара Загора; Кабинет по таласемия - СБАЛДБ, София; Сектор по таласемии, НЦХТ - София.

Материал и методи. Изследвани са 63 пациенти с $\beta$-таласемичен синдром, подложени на редовна хемотрансфузионна и хелатираща терапия.

Резултати. Един пациент с хроничен серозен отит и намален слух; 3 пациенти с хипертрофия на фарингеалната тонзила; 16 с хипертрофия на небните тонзили; 5 пациенти с девииран септум; 60 пациенти с хипохромна назална лигавица.

Ключови думи: $\beta$-таласемичен синдром, оториноларингология, намаление на слуха. хемотрансфузионен режим и редовна хелатираща терапия, много от клиничните прояви на болестта не се наблюдават или са леко изразени.

\section{Цел}

В настоящото проучване си поставихме за цел да изследваме оториноларингологичния статус на пациенти с $\beta$-таласемичен синдром, подложени на редовна хемотрансфузионна и хелатираща терапия.

\section{Материал и методи}

Проспективното проучване се провежда в четири центъра на територията на България - Клиника ОРЛ, Клиника по педиатрия, Клиника по вътрешни болести - Медицински факултет, Стара Загора; VI Вътрешно отделение - МБАЛ "Проф. Ст. Киркович", Стара Загора; Кабинет по таласемия - СБАЛДБ, София; Сектор по таласемии - НЦХТ, София.

В проучването участват 63 пациенти с $\beta$-таласемия, подложени на редовна хемотрансфузионна и хелатираща терапия. По данни на лабораторията по молекулярна патология към Медицински университет - София, пациентите с установен генетично $\beta$-таласемичен синдром в България са 214 [6].

От проучените 63 болни 33 са пациенти под 18 години, а останалите 30 са над 18 години. Разпределението на пациентите по възраст и по пол е представено на Табл. 1 и 2.

Таблица 1. Разпределение на пациентите по възраст

\begin{tabular}{|l|c|c|}
\hline \multicolumn{1}{|c|}{ Възраст } & Брой & $\begin{array}{c}\text { \% от общия } \\
\text { брой }\end{array}$ \\
\hline $0<r .<=5$ & 3 & 4,76 \\
\hline $5<r .<=10$ & 11 & 17,46 \\
\hline $10<r .<=15$ & 16 & 25,39 \\
\hline $15<r .<=20$ & 9 & 14,28 \\
\hline $20<r .<=25$ & 12 & 19,04 \\
\hline $25<r .<=30$ & 10 & 15,87 \\
\hline $30<r .<=35$ & 2 & 3,17 \\
\hline
\end{tabular}

Таблица 2. Разпределение на пациентите по пол

\begin{tabular}{|l|c|c|}
\hline & Брой & \% от общия брой \\
\hline Мъже & 34 & 53,96 \\
\hline Жени & 29 & 46,03 \\
\hline
\end{tabular}

Изследванията са извършени по предварително изготвена анкетна карта.

Основните клинико-диагностични методи за изследване на ОРЛ-статус при пациентите с таласемичен синдром бяха: 
1. Анамнеза - по данни на родителите при пациенти под 18 години или по данни на пациента за тези над 18 години. Обърна се внимание за наличие на промени в слуховата функция, свързани с таласемичния синдром, хемотрансфузиите и/или хелатиращата терапия. Търсят се минали отологични заболявания, както и такива, засягащи останалите ЛОР-органи. При събиране на информация за основното заболяване на пациентите използвахме основно данните от минала история на заболяването относно давността на таласемичния синдром и продължителността и естеството на терапията.

2. Локален ОРЛ-статус.

\section{1. Отоскопия, отомикроскопия.}

Освен класическата отоскопия е използван и отоскоп на Riester. Отбелязана бе целостта, цветът и подвижността на тъпанчевата мембрана.

2.2. Риноскопия - предна, а при необходимост и задна риноскопия.

2.3. Фарингоскопия - мезофарингоскопия.

3. Аудиометрични изследвания - тонална прагова аудиометрия, отоакустични емисии и слухови стволови евокирани потенциали.

4. Ориентировъчно изследване на вестибуларния анализатор - изследване за наличие на спонтанен нистагъм под очилата на Френцел; статокинетични проби.

\section{Резултати и обсъждане}

При всички изследвани от нас пациенти таласемичният синдром е установен в кърмаческа възраст. От момента на диагноза датират и редовните хемотрансфузии, средно на всеки 3 седмици в зависимост от нивото на претрансфузионния хемоглобин $[4,5]$.

При всички изследвани от нас пациенти се касае за хомозиготна $\beta$-таласемия, като при 62 пациенти се касае за таласемия майор $(98.41 \%, \mathrm{n}=63)$, а само при един случай за минорна форма. Затова при всички от изследваните е установена фамилна обремененост относно гена за таласемия.

При събиране на анамнестичните данни на пациентите с таласемичен синдром насочено се интересувахме за оториноларингологичните оплаквания на болните по изготвената анкетна карта, които са видни на Табл. 3. За хъркане по време на сън съобщават 3 пациенти на възраст под 10 години $(4.76 \%, n=63)$, което ние отдаваме на хипертрофия на назофарингеалната тонзила. Болки в гърлото, затруднено преглъщане и чести инфекции на ГДІ, включително гнойни ангини, се установиха само при 1 пациент $(1.58 \%, \mathrm{n}=63)$. Тези данни показват оториноларингологична заболяемост, която не се различава от тази на популацията [7].

Таблица 3. Оториноларингологични оплаквания по данни от анамнезата

\begin{tabular}{|l|c|c|}
\hline \multicolumn{1}{|c|}{$\begin{array}{c}\text { Анамнестични данни за } \\
\text { ОРЛ-заболявания }\end{array}$} & $\begin{array}{c}\text { Брой } \\
\text { пациенти }\end{array}$ & $\%$ \\
\hline Субективно намален слух & 1 & 1,58 \\
\hline $\begin{array}{l}\text { Оплаквания от носа и около- } \\
\text { носните кухини в миналото }\end{array}$ & 1 & 1,58 \\
\hline Затруднено носно дишане & 2 & 3,17 \\
\hline Хъркане по време на сън & 3 & 4,76 \\
\hline Чести инфекции на ГДП & 1 & 1,58 \\
\hline Вестибуларни нарушения & 0 & 0 \\
\hline
\end{tabular}

По отношение на други симптоми от страна на слуховия анализатор, като гноетечение от ушите, шум в ушите, световъртеж, нестабилност, гадене, повръщане и други, те не бяха регистрирани при нито един от изследваните от нас пациенти.

Отоскопията показа отклонение от нормата при един от изследваните пациенти $(1.58 \%, \mathrm{n}=63)$. При него цветът на дясната тъпанчева мембрана беше помътнен, рефлексът размазан, подвижността на мембраната леко ограничена, анатомичните подробности се визуализираха добре (Табл. 4).

Таблица 4. Данни от оториноларингологичния статус на изследваните пациенти

\begin{tabular}{|l|r|r|}
\hline \multicolumn{1}{|c|}{ Оториноларингологична находка } & Брой пациенти & $\%$ \\
\hline Абнормна тъпанчева мембрана & 1 & 1,58 \\
\hline Хипертрофия на фарингеалната тонзила & 3 & 4,76 \\
\hline Хипертрофия на небните тонзили & 16 & 25,39 \\
\hline Девиация на септума & 5 & 7,93 \\
\hline Стеснени носни ходове & 3 & 4,76 \\
\hline Секрет в носните ходове & 1 & 1,58 \\
\hline Хипохромна назална лигавица & 60 & 95,23 \\
\hline Отклонения от ориентировъчното изследване на вестибуларния анализатор & 0 & 0 \\
\hline
\end{tabular}


При 3 от изследваните $(4.76 \%, \mathrm{n}=63)$ се установи хипертрофия на фарингеалната тонзила, като тя бе определена 3-та степен. Тези пациенти бяха съобщили и за хъркане по време на сън.

Таблица 5. Хиперторфия на небните тонзили
Хипертрофия на небните тонзили беше регистрирана при 16 пациенти, като тя бе разграничена степенно, видно от Таблица 5.

\begin{tabular}{|c|c|c|c|c|}
\hline & Брой пациенти & Натрупване & \% от общия брой & \% с натрупване \\
\hline Без хипертрофия & 47 & 47 & 74,60 & 74,60 \\
\hline 1.степен & 6 & 53 & 9,52 & 84,12 \\
\hline 2.степен & 6 & 59 & 9,52 & 93,65 \\
\hline 3.степен & 4 & 63 & 6,34 & 100,00 \\
\hline
\end{tabular}

От изследваните от нас 63 пациенти $5(7.93 \%, \mathrm{n}=$ 63) бяха с девиация на носната преграда, която не смущаваше функционално дишането. При изследване на носните ходове се установи, че при 3 от изследваните $(4.76 \%, \mathrm{n}=63)$ те са стеснени. Слузно-гноен секрет в носните ходове се установи при 1 от изследваните. Назалната лигавица при 60 пациенти $(95.23 \%, \mathrm{n}=63)$ от случаите беше хипохромна, което е в съответствие с ниското ниво на претрансфузионен хемоглобин. Ливидна назална лигавица се установи при 1 пациент, а хиперемирана при двама. Средната стойност на нивото на претрансфузионен $\mathrm{Hb}$ е 85.14 g/l (Табл. 6), на $\mathrm{Er}$ $2.99 \times 10^{12}$, а средното ниво за серумния феритин е $3048 \mathrm{ng} / \mathrm{ml}$.

Таблица 6. Основни лабораторни резултати средни стойности

\begin{tabular}{|c|c|}
\hline $\mathrm{Hb}$ & $85,14 \mathrm{~g} / \mathrm{l}$ \\
\hline $\mathrm{Er}$ & $2,99 \times 10^{12} /$ \\
\hline $\mathbf{s F e r L}$ & $3048 \mathrm{ng} / \mathrm{ml}$ \\
\hline
\end{tabular}

Литература

1. Ефремов Г, Петков Г, Чакърова П. Таласемични синдроми. Издателство „ЗНАНИЕ” Стара Загора, 2003

2. Петков Г. Проучвания върху таласемичните синдроми в детска възраст. Дисертация за присъждане на научна степен доктор на медицинските науки, 1986.

3. Чакърова П. Корелация между генните дефекти и клиничната експресия при деца, болни от $\beta$-таласемия. Дисертация за присъждане на научна степен доктор по медицина, 1991

4. Чакърова П, Петков Г. Таласемични синдроми. Практически наръчник по педиатрия, 2001:565-9.
По отношение на ориентировъчното изследване на вестибуларния анализатор пациентите показаха постоянство в изследваните параметри, като не се установиха данни за спонтанен нистагъм или отклонения в статокинетичните проби.

\section{Изводи}

1. Честотата на оториноларигологични заболявания при пациенти с таласемичен синдром не се отличава от тази на общата популация за съответната възрастова група.

2. Поради повишения риск от оториноларингологични заболявания пациентите с таласемичен синдром подлежат на диспансерно наблюдение от УНГ-специалист.

Може да се предположи, че хемотрансфузионната терапия има модулиращ ефект върху имунната система на организма, което е обект на бъдещи проучвания.

5. Piomelli S. Current strategies in the management of Cooley's amenia. Ann.N.Y.Acad.Sci. 1985, 445:256

6. Лаборатория по молекулярна патология: $\beta$-таласемия (ОМIM 141900), СБАЛАГ „Майчин дом”, Медицински Университет София; http://www./mpbg. org/lib/dd1.htm.

7. Lucarelli, G.; Galimberti, M.; Polchi, P.; Angelucci, E.; Baronciani, D.; Giardini, C.; Politi, P.; Durazzi, S. M. T.; Muretto, P.; Albertini, F. Bone marrow transplantation in patients with thalassemia. New Eng. J. Med. 322: 417-421, 1990.

Адрес за кореспонденция:

Д-р Полина Ненчева

Клиника УНГ-болести, Тракийски университет - Стара Загора

ул. „Армейска" 11

E-mail:poli_nentcheva@hotmail.com 